\title{
Effect of Anthum Graveolens L. Extract on Biochemical and Histopathological Alteration of Deltamethrin in Rats
}

\author{
Somia I. El-Maghraby ${ }^{1 *}$, Hamdy A. Taha ${ }^{1}$ and Nabila S. Hassan ${ }^{2}$ \\ ${ }^{1}$ Department of Applied Organic Chemistry, National Research Center, Dokki, Giza, Egypt \\ ${ }^{2}$ Department of pathology, National Research Center, Dokki, Giza, Egypt
}

\begin{abstract}
Anthum graveolens (dill) seeds are a common and very effective household remedy for a wide range of digestive problems. The present study was performed to investigate the effect of dill extracts on altered biochemical parameters in deltamethrin-exposed rats. Deltamethrin was administered orally at doses 7.5 and $15 \mathrm{mg} / \mathrm{kg}$ of body weight on the basis of $\mathrm{LD}_{50}$ for 30 days. The sub-acute toxicity of pyrethroid insecticide deltamethrin varies markedly with the dose employed. Oral administration of plant extracts to rats for 30 days afforded a good protection against deltamethrin elevation in serum marker enzymes. They decreased the levels of aspartate aminotransferase (AST), alanine aminotransferase (ALT) and alkaline phosphatase (ALP) which was increased by DLM administration. Deltamethrin significantly increased the level of plasma total protein (TP), cholesterol and triglyceride. The concentration of urea and creatinine were also increased and all these parameters were decreased by the effect of plant extract. Results were also indicated that, the enzyme activities of acetyl cholinesterase (AchE), catalase (Cat) and glutathione-S-transferase (GST) were increased as compared to the DLM group. Dose dependant of histopathological changes which observed in both liver and kidney are also described.
\end{abstract}

Keywords: Deltamethrin; Anthum graveolens; Antioxidant enzymes; Biochemistry; Histopathological changes

\section{Introduction}

Synthetic pyrethroids constitute a unique group of insecticides having pyrethrum like structures with better performance characteristics and account for over $30 \%$ of insecticides used globally (Prasanthi et al., 2005). Pyrethroid insecticides show strong insecticidal properties, while their acute toxicity for humans and mammals is low. Deltamethrin [(s) $\alpha$-cyano-3phenoxy benzy1-(R)-cis-3-(2, 2-dibromoviny1)-2-2-dimethy1-cyclopropane carboxylate] a synthetic pyrethroid type İ. It is highly effective against a broad spectrum of insects with potent insecticidal properties (Manna et al., 2006). Major signs of acute poisoning by Type II compounds include salivation, hyperexcitability, tremors, and choreoathetosis (Soderlund et al., 2002; Wolansky et al., 2006). Deltamethrin is one of the most neurotoxic members of a relatively new and commonly used class of the pyrethroid insecticides (Kim et al., 2008). It is the most toxic one of pyrethrroids for vertebrates and it is used extensively not only as an ectoparasiticide in animals but also, in agricultural crop production and in public health programs (Manna et al., 2004a). The main sources of general population exposure to this pesticide are contaminated food and water.
Deltamethrin is readily absorbed by the oral route (Barlow et al., 2001). Several studies have shown that, pyrethroid caused alterations in biochemistry, hematology and reproduction (Yousef et al., 2006; El-Demerdash et al., 2004). Repeated daily oral doses of pyrethroid insecticide of $\alpha$-cypermethrin at 1/10LD50 altered the biochemical parameters, decreased cytochrome P450 content, antioxidant status which correlated with histopathological changes of tissues (Manna et al., 2004b).

Therefore, the present study was undertaken to determine the effects of deltamethrin on biochemistry, enzyme activities, and histopathological changes in liver and kidney of male rats, and also to investigate the role of dill plant extracts in alleviating the harmful effects of deltamethrin on these experimental animals.

\section{Materials and Methods}

\section{Chemical}

Deltamethrin, (purity over 98\%), was synthesized in our laboratory, according to known method (Lee et al., 1998). The oral $\mathrm{LD}_{50}$ of Deltamethrin to rats was reported to be $150 \mathrm{mg} / \mathrm{kg}$ body weight (Manna et al., 2004a). Deltamethrin was administered orally at $1 / 10 \mathrm{LD}_{50}(15 \mathrm{mg} / \mathrm{kg})$ and $1 / 20 \mathrm{LD}_{50}(7.5 \mathrm{mg} / \mathrm{kg})$.

\section{Plant material and extraction}

Anthum graveolens (Dill) plants were locally collected, washed, dried and powdered in grinding mill. Plants then kept for 14 days in $20 \%$ methanol with daily shaking and the filtrate was used for treatment. After, evaporation $10 \mathrm{~g}$ of the extracts were obtained from $100 \mathrm{~g}$ of the materials which, was corresponding to the $10 \%$ of the $100 \mathrm{~g}$ of starting plant materials.

\section{Animals}

Male Wister rats, aged 20-21 weeks and weighing 160 \pm 20 g, were selected from inbred colony maintained in the animal house of the National Research Center, Giza, Egypt under controlled conditions of temperature at $25 \pm 2^{\circ} \mathrm{C}$, relative humidity of $50 \pm 15 \%$ and normal photoperiod (12h dark: $12 \mathrm{~h}$ light). Animals were housed throughout the experiment in polypropylene

*Corresponding author: Somia I. El-Maghraby, Assistant professor in NRC, Department of Applied Organic Chemistry, National Research Center, Dokki, Giza, Egypt, Fax: +202 33370931; E-mail: somiaibrahem@yahoo.com

Received February 05, 2010; Accepted March 13, 2010; Published March 13, 2010

Citation: El-Maghraby SI, Taha HA, Hassan NS (2010) High Performance Liquid Chromatographic Method for the Determination of Clobetasol in Rat Plasma and its Application to Skin Penetration. J Bioanal Biomed 2: 008012. doi:10.4172/1948-593X.1000014

Copyright: ( $) 2010 \mathrm{El}$-Maghraby SI, et al. This is an open-access article distributed under the terms of the Creative Commons Attribution License, which permits unrestricted use, distribution, and reproduction in any medium, provided the original author and source are credited. 
cages (with each cage housing six animals), where fed on pellet diet and water ad libitum and allowed to acclimatize to the laboratory environment for 7 days.

\section{Experimental design}

After, one week of acclimation, rats were randomly divided into six groups each containing six animals and the route of administration which selected for the study was oral (using oral feeding needles). The animals were grouped as follows: group 1 (control) received dismethylsulphoxide (DMSO) $(1 \mathrm{ml})$ for each animal; while group 2 and 3 were fed Deltamethrin dissolved in DMSO (1ml) at doses 15 and $7.5 \mathrm{mg} / \mathrm{kg}$ body weight corresponding to $\mathrm{LD}_{50}$; group 4 received plant extract only $(100 \mathrm{mg} /$ $\mathrm{kg}$ b.w); and group 5 and 6 received deltamethrin at a dose $15 \mathrm{mg} /$ $\mathrm{kg}$ b.w. and $7.5 \mathrm{mg} / \mathrm{kg}$ b.w. plus dill extract, respectively. Treatment duration was daily once in a day for one month.

\section{Hematological analysis}

Throughout the treatment period, the blood samples from six rats were collected under light ether anasethesia from the orbital plexus of the treated and control groups. Blood was collected in dry test tubes containing heparin as anticoagulant and plasma samples were obtained by centrifugation at 3000xg for $15 \mathrm{~min}$ and kept in a refrigerator till measurements. Mice were examined at 30 days for changes in plasma acetyl cholinesterase enzyme activity using acetyl thiocholine iodide as a substrate according to Ellman et al. (1961) In plasma, alanine aminotransferase (ALT), aspartate aminotransferase (AST) (Reitman and Frankel, 1957), and alkaline phosphatase (ALP) (Kind et al., 1954), were measured. Catalase (CAT) and glutathione Strasferase (GST) enzyme activity was determined according to Aebi and Habig, (1954), (Habig et al., 1974), respectively. Plasma samples were analyzed for protein concentration by the biuret method (Gornall et al., 1949). Serum albumen concentration was determined using the Sigma diagnostics albumen reagent (Sigma chemical), this methods is based on the procedure of Doumas et al. (1971). Blood urea nitrogen concentration was determined according to Urease-modified Berthelot reaction (Charles and Crouch, 1997). Serum creatinine determination was carried out according to Jaffe reaction (Harry and Abraham, 1968). Also, plasma was assayed for cholesterol (Cho) and trigylycerides (TG) by method of Carr et al. (Carr et al., 1993).

\section{Histopathological examination}

Small pieces of liver and kidney were fixed in $10 \%$ neutral buffered formalin and fixed in Bouin's fluid. Sections of 3-5m thicknesses were cut and stained with haematoxylin and eosin (H\&E) for observation under light microscope.

\section{Statistical analysis}

The results of biochemical tests obtained were subject to statistical analysis by means of a Student's $t$ parametric test.

\section{Results and Discussion}

\section{Biochemical studies}

As shown in Table 1 and Table 2, the toxicity of daltamethen varies markedly with the dose employed. Treatment with deltamethrin at high dose $\left(1 / 10 \mathrm{LD}_{50}\right)$ increased the activities of aminotrasferase enzyme in rats compared to low dose $\left(1 / 20 \mathrm{LD}_{50}\right)$ treated group. Oral administration of rats with $15 \mathrm{mg} / \mathrm{kg}$ body weight deltamethrin for 30 days showed significantly increased J Bioanal Biomed in alanine and aspartate aminotransferase (ALT and AST) enzyme activities compared to control animals (Table 1). Pyrethroids, which belong to highly active insecticides, show relatively low toxicity for humans. The studies conducted on animals indicate that, the toxicity of the preparation depends on many factors, such as, body construction, route of administration, period of administration, and substance in which, the preparation was administered (Luty et al., 2001). The increase in plasma aminotransferase (ALT and AST) enzyme activities in rats treated with deltamethrin (Table 1) is in agree with the finding of Yousef et al. (2006) and El-Demerdash et al. (2004). The increase in these enzyme activities is indicative for liver damage and thus causes alteration in liver function as we noticed in our pathological studies. Awad et al. (1998) found that cell damage exhibited good correlation with the enzyme leakage. In the present study, the increase in AST and ALT of plasma caused by toxic substances may be due to liver dysfunction and disturbance in the biosynthesis of these enzymes. There is a moderate elevation in alkaline phosphate (ALP) enzyme activities indication with the two doses. Results also showed that, the activities of catalase (Cat), glutation-S-trasferase (GST), and acetylcholinesterase enzymes were significantly decreased in plasma of rats treated with deltamethrin (Table 1). Treatment with dill plant extract alone did not caused significant changes in the enzyme activities in plasma, while, the plant extract in combination with deltamethrin alleviated the negative effects of the insecticide on the activities of the above measured enzymes. Phosphatases are important and critical enzymes in biological processes (Khan et al., 2001). The increase in ALP obtained in this study are in accordance with the finding of El-Demerdash et al. (2004) Rahman et al. (2000) reported that, the increase in the activity of these enzymes in blood might be due to, the necrosis of liver and kidney. The decrease in Cat and GST (Table 1) is in agreement with the results of Yousef et al. (2006) and Kale et al. (1999), which showed oxidative stress and alteration in antioxidant enzymes in erythrocytes of pyrethroid intoxicant rats. This may be the result of free radical production or a direct action of pesticides on the synthesis of enzyme (Oruc and Uner, 2000). It is worth to mention that, the decrease in the activity of AchE is in connection with the observation of Yousef et al. (2001) and El-Demerdash et al. (2004). This decrease in AchE activity may be due to, the decrease of the enzyme synthesis by the inhibitory nature of toxicant. Data represented in Table 2 showed that, treatment with deltamethrin, especially in higher dose, caused significant decrease in plasma total protein (TP) and albumen (Alb). On the other hand, data showed a slight increase in creatinine concentration and moderate increase in urea concentration in treated group as compared with control one after 30 days of treatment. Data represented in Table 2 showed also that, deltamethrin administration with higher dose causes significant increase in the concentration of cholesterol (Cho), while, the concentration of triglycerides (TG) was moderately increased at the end of the experiment comparing with the control group. Rats treated with plant extract only, showed a slight decrease in lipid profile, and increased plasma total protein and albumen. So, the presence of dill extract with deltamethrin was minimized its toxic effects and reduced the elevation of urea and creatinine concentration (Table 2). Rivarola and Balegno, (1991) reported that, the reduction in plasma protein, particularly albumen, in mammals treated with pesticides could be attributed to changes Volume 2(1) : 008-012 (2010) - 009 


\section{Journal of Bioanalysis \& Biomedicine - Open Access \\ JBABM/Vol.2 Issue 1}

\begin{tabular}{|l|l|l|l|l|l|}
\hline Enzymes & Control & $\begin{array}{l}\text { DLM } \\
\left(1 / 10 D_{50}\right)\end{array}$ & $\begin{array}{l}\text { DLM } \\
\left(1 / 20 L_{50}\right)\end{array}$ & $\begin{array}{l}\text { DLM+dill } \\
\left(1 / 20 L D_{50}\right)\end{array}$ \\
\hline ALT(U/L) & $40 \pm 3.98$ & $77 \pm 4.67 * *$ & $68 \pm 3.01^{*}$ & $40 \pm 1.05$ & $51 \pm 2.72$ \\
\hline AST(U/L) & $100 \pm 3.90$ & $131 \pm 6.00^{* *}$ & $124 \pm 4.11^{*}$ & $105 \pm 2.43$ & $42 \pm 1.94$ \\
\hline ALP(U/L) & $57 \pm 1.43$ & $68 \pm 4.11^{*}$ & $66 \pm 3.45^{*}$ & $55 \pm 1.60$ & $115 \pm 2.15$ \\
\hline CAT(u/mg protein) & $0.34 \pm 0.04$ & $0.18 \pm 0.01^{* *}$ & $0.21 \pm 0.02^{*}$ & $0.34 \pm 0.03$ & $62 \pm 3.73$ \\
\hline GST $(\mu / \mathrm{mg}$ protein) & $1.92 \pm 0.13$ & $1.72 \pm 0.07^{*}$ & $1.78 \pm 0.10$ & $1.97 \pm 0.07$ & $0.26 \pm 0.02$ \\
\hline AchE $(\mu \mathrm{mol} / \mathrm{min} / \mathrm{ml})$ & $2.46 \pm 0.13$ & $1.92 \pm 0.10^{* *}$ & $2.15 \pm 0.24$ & $2.45 \pm 0.16$ & $0.30 \pm 0.01$ \\
\hline
\end{tabular}

Values are expressed as means \pm SD

$\mathrm{n}=6$ for each treatment group.

* Significant at $p<0.05$ in comparison with control.

** Significant at $\mathrm{p}<0.01$ in comparison with control.

ALT: alanine aminotransferase, AST: aspartate aminotransferase, ALK: alkaline phosphatase, CAT: catalase,

GST: glutathione S-transferase, AchE: acetylecholinesterase.

Table 1: Effect of dill plant extract on the activities of plasma enzymes after daily oral administration with deltamethrin (DLM), at $15 \mathrm{mg} / \mathrm{kg}$ and $7.5 \mathrm{mg} / \mathrm{kg}$ body weight, for 30 days.

\begin{tabular}{|c|c|c|c|c|c|c|}
\hline $\begin{array}{l}\text { Parameters } \\
(\mathrm{g} / \mathrm{dl})\end{array}$ & Control & $\begin{array}{l}\text { DLM } \\
\left(1 / 10 \mathrm{LD}_{50}\right)\end{array}$ & $\begin{array}{l}\text { DLM } \\
\left(1 / 20 \mathrm{LD}_{50}\right)\end{array}$ & Dill & $\begin{array}{l}\text { DLM+dill } \\
\left(1 / 10 \mathrm{LD}_{50}\right)\end{array}$ & $\begin{array}{l}\text { DLM+dill } \\
\left(1 / 20 \mathrm{LD}_{50}\right) \\
\end{array}$ \\
\hline Total protein & $6.07 \pm 0.88$ & $5.00 \pm 0.48 * *$ & $5.36 \pm 0.42 *$ & $6.15 \pm 0.59$ & $5.75 \pm 0.40 *$ & $6.09 \pm 0.94$ \\
\hline Albumin & $3.14 \pm 0.20$ & $2.21 \pm 0.29 * *$ & $2.62 \pm 0.38^{* *}$ & $3.20 \pm 0.27$ & $2.75 \pm 0.09 *$ & $3.05 \pm 0.43$ \\
\hline Urea & $40.0 \pm 2.58$ & $71.0 \pm 4.97 * *$ & $64.0 \pm 3.60 * *$ & $38.0 \pm 1.49$ & $44.0 \pm 2.26$ & $40.0 \pm 3.60$ \\
\hline Creatinine & $0.72 \pm 0.04$ & $1.01 \pm 0.06^{*}$ & $0.81 \pm 0.16^{*}$ & $0.72 \pm 0.05$ & $0.76 \pm 0.02$ & $0.70 \pm 0.01$ \\
\hline Cholesterol & $162 \pm 5.30$ & $198 \pm 7.82^{* *} *$ & $180 \pm 6.33^{*}$ & $141 \pm 5.81$ & $175 \pm 6.43^{*}$ & $163 \pm 5.40$ \\
\hline Triglycerides & $131 \pm 2.96$ & $163 \pm 4.32 * *$ & $143 \pm 3.50 *$ & $121 \pm 4.21$ & $150 \pm 3.98 *$ & $134 \pm 4.11$ \\
\hline
\end{tabular}

Values are expressed as means \pm SD

$\mathrm{n}=6$ for each treatment group.

* Significant at $\mathrm{p}<0.05$ in comparison with control.

** Significant at $\mathrm{p}<0.01$ in comparison with control.

Table 2: Effect of dill plant extract on plasma biochemistry of rats treated daily with deltamethrin (DLM) at $15 \mathrm{mg} / \mathrm{kg}$ and $7.5 \mathrm{mg} / \mathrm{kg}$, body weight, for 30 days.

in protein and free amino acid metabolism and their synthesis in the liver. The decrease in TP and Alb observed in Table 2, are agree with finding of Yousef et al. (2006) Abnormal elevation on blood urea and creatinine are more specific and sensitive indicator of impaired kidney function (Cameron, 1996). In this connection, the present study fined analogy to those observed on the pathological sections (Figure 7). The increase in the cholesterol and triglycerides (Table 2) in the present study was agree with the finding of Yousef et al. (2006), which showed that, lipid concentration were affected following deltamethrin exposure to rats. Dill has anti-microbial activities, it contains some chemicals which exhibit antimycobacterial activities, and the chemicals include oxypeucedanin, oxypeucedanin hydrate and falcarindiol (Stavri and Gibbons, 2005). It is essential oil shows activities against some Gram-positive and negative bacteria as well as fungi (López et al., 2005). Dill also has anti-oxidant activities. The antioxidant activity of the aqueous extracts of dill is comparable with ascorbic acid, alpha-tocopherol and quercetin in in-vitro systems (Satyanarayana, 2004). Serum triacylglycerides and total cholesterol levels in rats, with hyperlipidaemia induced by diet, were determined after oral administration of a water extract of Anethum graveolens leaves before and after the extraction of the furocoumarin content of the leaves. Administration of the extracts consecutively for 14 days reduced the triacylglycerides and total cholesterol levels by almost 50 and $20 \%$, respectively. Oral administration of the essential oil of A. graveolens seeds, at two different doses, also reduced the triacylglyceride levels by almost $42 \%$ (Hajhashemi and Abbasi, 2008).

The obtained data indicated that, the presence of dill extract with deltamethrin alleviated its harmful effects on most of the measured parameters Table 1and Table 2. In general, this present data reported that, rat treated with dill plant extract alone not detect significant changes in most biochemical parameters.

\section{Histopathological studies}

Liver section of both control group and treated group with dill plant extract showed normal histological pictures. Examination of $\mathrm{H} \& \mathrm{E}$ sections of livers of control and treated extract rats shown that, the parenchyma was formed of classic hepatic lobules having the central veins in their middle, branching and anastomosing cords of hepatocytes radiate, and normal hepatocytes architecture and blood vessel (Figure 1).

Examination of rat liver treated with deltamethin at low dose $(7.5 \mathrm{mg} / \mathrm{kg} \mathrm{b.w})$ showed periportal fibrosis and congestion with deeply eosinophilic hyaline material in some hepatocytes. Liver of rats treated with the high dose of deltamethrin $\left(1 / 10 \mathrm{LD}_{50}\right)$ revealed deformed in some hepatocytes structure, thickening of their portal tract as well as, fibrosis and coagulative necrosis. High dose administration also, showing early fatty degeneration mainly hepatocytes around the central vein and deeply eosinophilic hyaline material, moreover, interstitial infiltration and

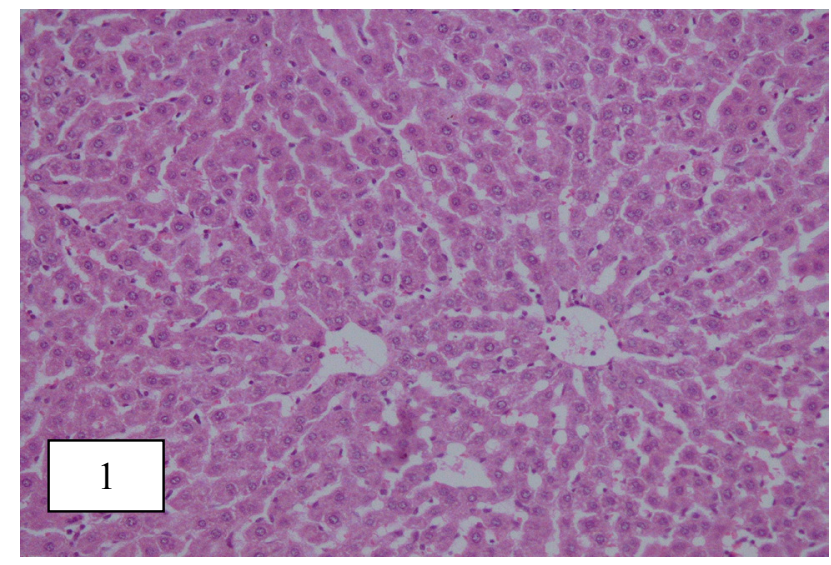

Figure 1: A photomicrograph in a section of control rat liver showing the central vein normal hepatocytes architecture. (HX \& E. X200). 
Citation: El-Maghraby SI, Taha HA, Hassan NS (2010) High Performance Liquid Chromatographic Method for the Determination of Clobetasol in Rat Plasma and its Application to Skin Penetration. J Bioanal Biomed 2: 008-012. doi:10.4172/1948-593X.1000014

focal necrosis were scattered (Figure 2). Inspected liver sections obtained from rats treated with deltamethrin at low and high doses in combination with dill plant extract revealed histological structure that was approximately similar to those of control animals where most of the hepatocytes around central veins appeared nearly normal, while the portal tract still thick walled and surrounded by fibrous tissues (Figure 3).

Kidney sections of the control and treated extract rats were shown to be formed of stroma and parenchyma. The parenchyma was divided into cortex and medulla. The cortex comprised renal corpuscles, proximal and distal convoluted tubules (Figure 4). Kidney sections of rat liver treated with deltamethin at low dose showing collapsed glomeruli, focal tubular necrosis and cellular debris. The kidney of rats treated with the high dose showed expanding in glomerular space and tufts with congestion and increase in mesangial cells. Moreover, interstitial inflammatory cells and congestion were noticed. Some of the renal tubules exhibited necrosis and pyknosis in their epithelial cells beside cellular debris in dilated renal tubules. Other renal tubules revealed swelling, obliteration and hyper chromatic nuclei (Figure 5). The treatment with dill plant extract with low or high dose of insecticide revealed more or less normal picture of

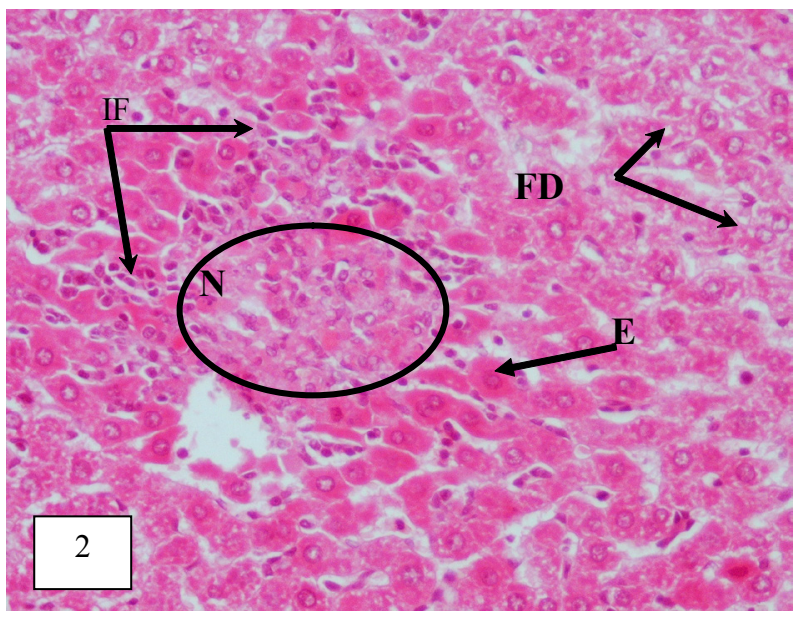

Figure 2: A section of rat liver treated with $15 \mathrm{mg} / \mathrm{kg}\left(1 / 10 \mathrm{LD}_{50}\right)$ deltamethrin showing hepatocytes around the central vein with early fatty degeneration (FD), deeply eosinophilic hyaline material (E), interstitial infiltration (IF) and focal necrosis (N). (HX \& E. X400).

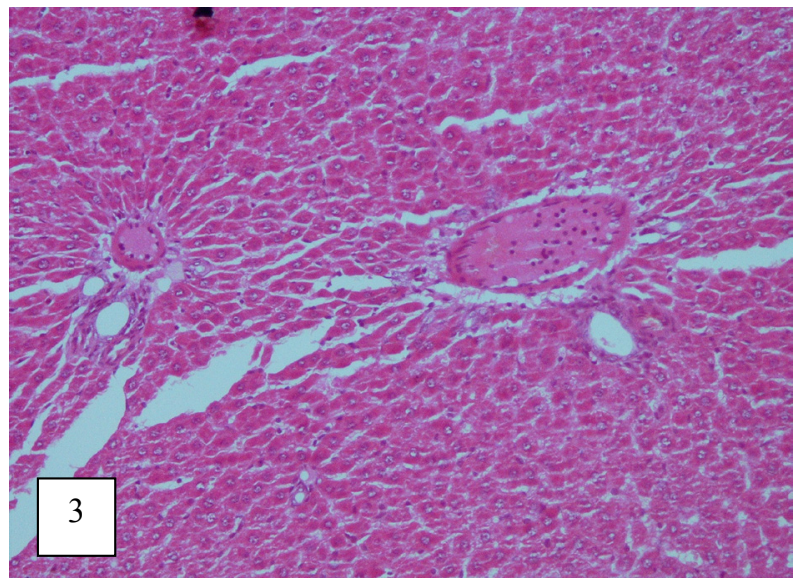

Figure 3: A section of rat liver treated with high dose of deltamethrin $\left(1 / 10 \mathrm{LD}_{50}\right)$ + Dill plant extracts showing moderate improvement in hepatic cells while portal tracts still abnormal. (HX \& E. X200).

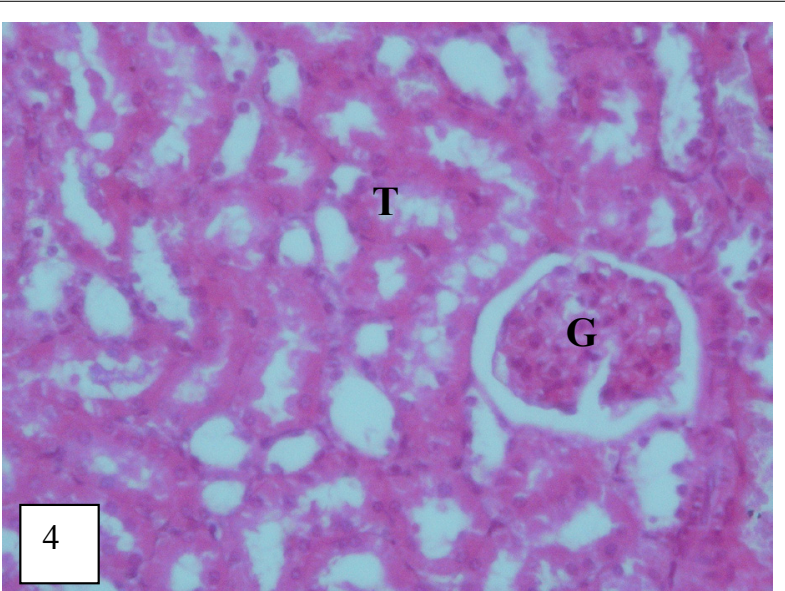

Figure 4: A photomicrograph of a section in the kidney of the control rat showing normal structure: glomerulus's (G), and renal tubules (T). (HX \& E. X400).

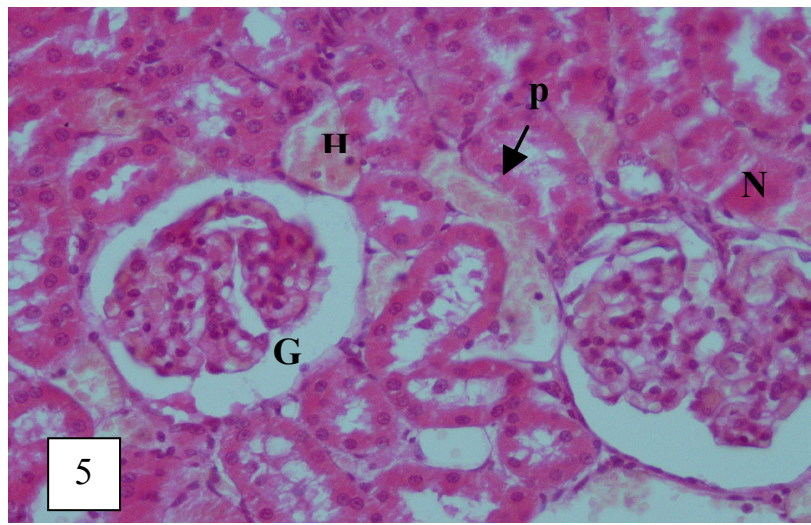

Figure 5: A photomicrograph in a section in the kidney of rat treated with high dose of deltamethrin showing expanding glomeruli with congestion and increase in mesangial cells $(\mathrm{G})$, interstitial inflammatory cells and congestion $(\mathrm{H})$, necrosis $(\mathrm{N})$ and pyknosis (P) in epithelial cells (HX \& E. X400).

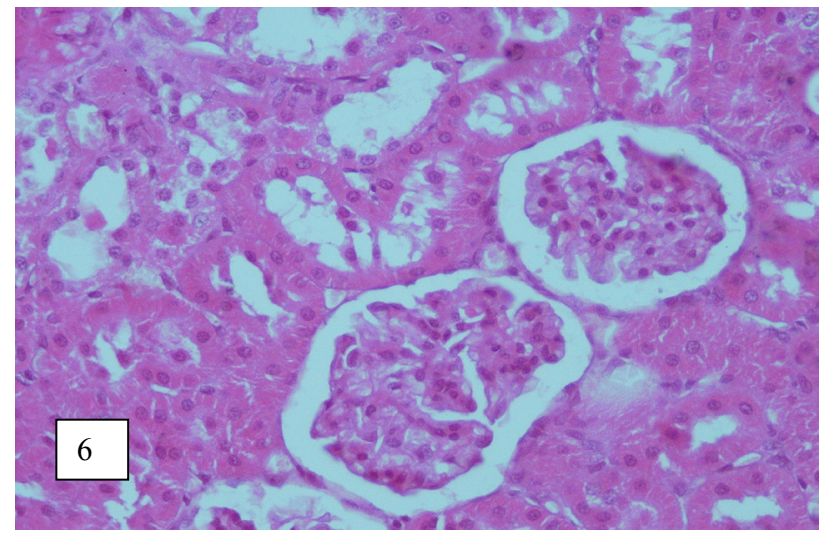

Figure 6: A photomicrograph in a kidney section of rat treated with high dose of deltamethrin+ Dill plant extract showing renal tubules and glomeruli. (HX\& E. X400).

renal tubules and glomeruli in low dose and same picture of expanded glomeruli and moderate improvement in renal tubules structure in high dose group (Figure 6). The histological changes indicated in liver (Figure 2) and kidney (Figure 5) are in agreement with the results of Perger and Szadkowski, (1994) who showed that in subchronic studies of pyrethroids toxicity in experimental animals which received high doses of the preparations, hypertrophy in the liver and kidney were observed. An oral administration of cypermethrin to mice for 28 days in the 


\section{Journal of Bioanalysis \& Biomedicine - Open Access JBABM/Vol.2 Issue 1}

doses of $1 / 5$ and $1 / 2 \mathrm{LD}_{50}$ led to generative changes and inflammatory infiltrations in the liver and kidney, especially after a higher dose of the preparation (Luty et al., 2000). Rats treated with deltamethrin at higher dose $\left(1 / 10 \mathrm{LD}_{50}\right)$ tend to offuscatio parenchymatosa renis, hypertrophy of Bowman capsules and hyaline casts of the renal cortex and these results are in connection with the finding of Luty et al. (2001) Several studies have indicated that, reactive oxygen species have been implicated in the toxicology of pyrethroids (Kale et al., 1999), so, the protective effect of dill plant extract, observed in our study could be important for protecting the different tissues against the oxidative injury which following the use of deltamethrin.

\section{References}

1. Aebi H (1984) Catalase in vitro. Methods Enzymol 105: 121-126. » CrossRef » PubMed » Google Scholar

2. Awad ME, Abdel-Rahman MS, Hassan SA (1998) Acrylamide toxicity in isolated rat hepatocytes. Toxicol In Vitro 12: 699-704. »CrossRef » PubMed » Google Scholar

3. Barlow SM, Sullivan FM, Lines J (2001) Reskassessment of the use of deltamethrin on bednets for the prevention of malaria. Food Chem Toxicol 39: 407-422. » CrossRef » PubMed » Google Scholar

4. Cameron JS (1996) Kidney Failure: The Facts. Oxford University Press New York 1996. »CrossRef » PubMed » Google Scholar

5. Carr T, Andressen CJ, Rudel LL (1993) Enzymatic determination of triglyceride, free cholesterol and total cholesterol in tissue liquid extracts. Clin Chem 26: 39-42. »CrossRef » PubMed » Google Scholar

6. Charles J, Crouch SR (1977) Spectrophotometric and kinetics investigation of the Berthelot reaction for the determination of ammonia. Analytical Chemistry 49: 464-470. » CrossRef » PubMed » Google Scholar

7. Doumas B, Watson W, Biggs H (1971) Albumin standards and the measurement of serum albumin with bromcresol green. Clin Chem Acta 31: 87-96. »CrossRef » PubMed » Google Scholar

8. El-Demerdash FM, Yousef MI, Kedwany FS, Baghdady HH (2004) Role of $\alpha$ tochopherol and $\beta$-carotene in ameliorating the fenvalerate-induced changes in oxidative stress, hematobiochemical parameters and semen quality of male rats. J Environ Sci Health B 93: 443-459.» CrossRef » PubMed » Google Scholar

9. Ellman GL, Courtney KD, Andres V Jr, Featherstone RM (1961) A new and rapid colorimetric determination of acetyl-cholinesterase activity. Biochem Pharmacol 7: 88-95. » CrossRef » PubMed » Google Scholar

10. Gornall AC, Bardawill CJ, David MM (1949) Determination of serum proteins by means of Biuret reaction. J Biol Chem 177: 751-766. »CrossRef » PubMed » Google Scholar

11. Habig WH, Pabst MJ, Jakoby WB (1974) Glutathion S-transferases. The first enzymatic step in mercapturic acid formation. J Biol Chem 249: 7130-7139. »CrossRef » PubMed » Google Scholar

12. Hajhashemi V, Abbasi N (2008) Hypolipidemic activity of Anethum graveolens in rats. Phytother Res 22: 372-375. »CrossRef » PubMed » Google Scholar

13. Harry H, Abraham R (1968) Estimation of creatinine by Jaffe reaction. Acomparison of three methods. Clin Chem 14: 222-228. »CrossRef » PubMed » Google Scholar

14. Kale M, Rathore N, Jone S, Bhatnagar D (1999) Lipid peroxidative damage on pyrethroid exposure and alterations in antioxidant status in rat erythrocytes: a possible involvement of reactive oxygen specie. Toxicol Lett 105: 197-205. »CrossRef » PubMed » Google Scholar

15. Khan IA, Reddy BV, Mahboob M, Rahman MF, Jamil K (2001) Effect of B 36: 445-456. » CrossRef » PubMed » Google Scholar

16. Kim KB, Anand SS, Kim HJ, White CA, Bruckner JV (2008) Toxicokinrtics and tissue distribution of deltamethrin in adult Sprague-Dawley rats. Toxicol Sci 101: 197-205. CrossRef » PubMed » Google Scholar phosphorothioate on the reproductive system of male rats. J Environ Sci Health

17. Kind PRN, King EG (1954) Estimation of plasma phosphatase by determination of hydrolysed phenol with amino antipyrine. Journal of clinical pathology 7: 322-326. » CrossRef » PubMed » Google Scholar

18. Lee N, McAdam DP, Skerritt JH (1998) Development of immunoassays for type II synthetic pyrethroids. I. Hapten design and application to heterologous assays. J Agric Food Chem 46: 520-534. » CrossRef » PubMed » Google Scholar

19. López P, Sánchez C, Batlle R, Nerín C (2005) Solid- and vapor-phase antimicrobial activities of six essential oils: susceptibility of selected foodborne bacterial and fungal strains. J Agric Food Chem 53: 6939-46. » CrossRef » PubMed » Google Scholar

20.Luty ST, Haratym-Maj A, Latuszynska J, Obuchowska-Przebirowska D, Tokarska-Rodak M(2001) Oral toxicity of deltamethrin and fenvalerate in swiss mice. Ann Agric Environ Med 8: 245-254. » CrossRef » PubMed » Google Scholar

21. Luty ST, Latuszynska J, Obuchowska-Przebirowska D, Tokarska-Rodak M, Haratym-Maj A (2000) Subacute toxicity of orally applied alphacypermethrin in swess mice. Ann Agric Environ Med 7: 33-41. » CrossRef » PubMed » Google Scholar

22. Manna S, Bhattacharyya D, Mandal TK, Dey S (2006) Neuropharmaco-logical effects of deltamethrin in rats. J Vet Sci 7: 133-136. »CrossRef » PubMed » Google Scholar

23. Manna S, Bhattacharyya D, Mandal TK, Das S (2004a) Repeated dose toxicity of alfa-cypermethrin in rats. J Vet Sci 5: 241-245. »CrossRef » PubMed » Google Scholar

24. Manna S, Bhattacharyya D, Mandal TK (2004b) Single oral dose toxicity study of deltamethrin in rats. Indian Vet Med J 28: 237-241. » CrossRef » PubMed » Google Scholar

25. Oruc EO, Uner N (2000) Combined effects of 2,4-D and azinophosmethyl on antioxidant enzymes and lipid peroxidation in liver of Oreochromis niloticus Comp. Biochem Physiol Part C 127: 291-296. »CrossRef » PubMed » Google Scholar

26. Perger G, Szadkowski D (1994) Toxicology of pyrethroids and their relevance to human health. Ann Agric Environ Med 1: 11-17. »CrossRef » PubMed » Google Scholar

27. Prasanthi K, Muralidhara Rajini PS (2005) Fenvalerate-induced oxidative damage in rat tissues and its attenuation by dietary sesame oil. Food Chem Toxicol 43: 299-306. » CrossRef » PubMed » Google Scholar

28. Rahman MF, Siddiqui MK, Jamil L (2000) Acid and alkaline phosphatase activities in a novel phosphorothioate (RPR-11) treated male and female rats. Evidence of dose and time-dependent response. Drug Chem Toxicol 23: 497 509. »CrossRef » PubMed » Google Scholar

29. Reitman S, Frankel S (1957) Determination of serum glutamic oxaloacetic and glutamic pyruvic transaminases. American Journal of clinical pathology 28, 56-60. » CrossRef » PubMed » Google Scholar

30. Rivarola VA, Balegno HF (1991) Effect of 2, 4-dichlorophenxyacetic acid on polyamine synthesis in Chinese hamster ovary cells. Toxicol Lett 56: 151-157. »CrossRef » PubMed » Google Scholar

31. Soderlund DM, Clarc GM, Sheets LP, Mullin LS, Piccirillo VJ, (2002) Mechanismes of pyrethroid neurotoxicity: Implications for cumulative risk assessment. Toxicology 171: 3-59.» CrossRef » PubMed » Google Scholar

32. Satyanarayana S (2004) The extracts of dill fruits show antioxidant activities in an in-vitro study. J Herb Pharmacother 4: 1-10.» CrossRef » PubMed » Google Scholar

33. Stavri M, Gibbons S (2005) The antimycobacterial constituents of dill (Anethum graveolens). PhytotherRes 19: 938-41.»CrossRef » PubMed » Google Scholar

34. Wolansky MJ, Gennings C, Crofton KM (2006) Relative potencies for acute effects of pyrethroids on motor function in rats. Toxicol Sci 89: 271-277. »CrossRef » PubMed » Google Scholar

35. Yousef MI, Awad TI, Mohamed EH (2006) Deltamethrin-induced oxidative damage and biochemical alterations in rat and its attenuation by vitamin $\mathrm{E}$. Toxicology 227: 240-247. »CrossRef » PubMed » Google Scholar

J Bioanal Biomed

Volume 2(1) : 008-012 (2010) - 012

ISSN:1948-593X JBABM, an open access journal 